\title{
Stem Cells and Nuclear Reprogramming
}

\author{
Fuliang Du, ${ }^{1}$ Mark G. Carter, ${ }^{2}$ Giorgio A. Presicce, ${ }^{3}$ \\ Shinn-Chih $\mathrm{Wu}^{4}{ }^{4}$ and Perng-Chih Shen ${ }^{5}$
}

${ }^{1}$ Renova Life Inc., University of Maryland, College Park, MD 20742, USA

${ }^{2}$ Center for Regenerative Biology, University of Connecticut, Storrs, CT 06269, USA

${ }^{3}$ Consorzio di Ricerca e Sperimentazione per gli Allevatori (CRSA), 00161 Rome, Italy

${ }^{4}$ Department of Animal Science and Technology, National Taiwan University, Taipei 106, Taiwan

${ }^{5}$ Department of Animal Science, National Pingtung University of Science and Technology, Pingtung 912, Taiwan

Correspondence should be addressed to Fuliang Du, fuliangd@renovalife.com

Received 18 August 2011; Accepted 18 August 2011

Copyright ( $) 2011$ Fuliang Du et al. This is an open access article distributed under the Creative Commons Attribution License, which permits unrestricted use, distribution, and reproduction in any medium, provided the original work is properly cited.

Stem cells are found in all multicellular organisms, including two broadly defined cell types: embryonic stem cells (ESC) (C. Y. Cheong and T. Lufkin; and N. Lifantseva et al.) that are derived from the inner cell mass of blastocyststage embryos and adult stem cells that are present in adult tissues (C. M. Teven et al., R. Chung et al., and A. C. Wilber et al.). Nuclear reprogramming refers to the erasure and remodeling of epigenetic marks, which is a part of normal mammalian development. This reprogramming is likely required for totipotency of the newly formed embryo and erasure of acquired epigenetic changes (Felici). Advances in stem cells including induced pluripotent stem (IPS) cells (D. Dey and G. R. D. Evans; and P. Noisa and R. Parnpai) and nuclear reprogramming (C. M. Teven et al.) will provide new insights into the mechanisms of cellular differentiation, during embryonic development (N. Lifantsevaa et al.) as well as in adult tissues (C. M. Teven et al.), and their pluripotency (A. C. Wilber et al.), which may lead to cell-based therapies (R. Eggenschwiler et al.) for several human diseases (R. Chung et al.).

Fuliang Du

Mark G. Carter

Giorgio A. Presicce

Shinn-Chih Wu

Perng-Chih Shen 

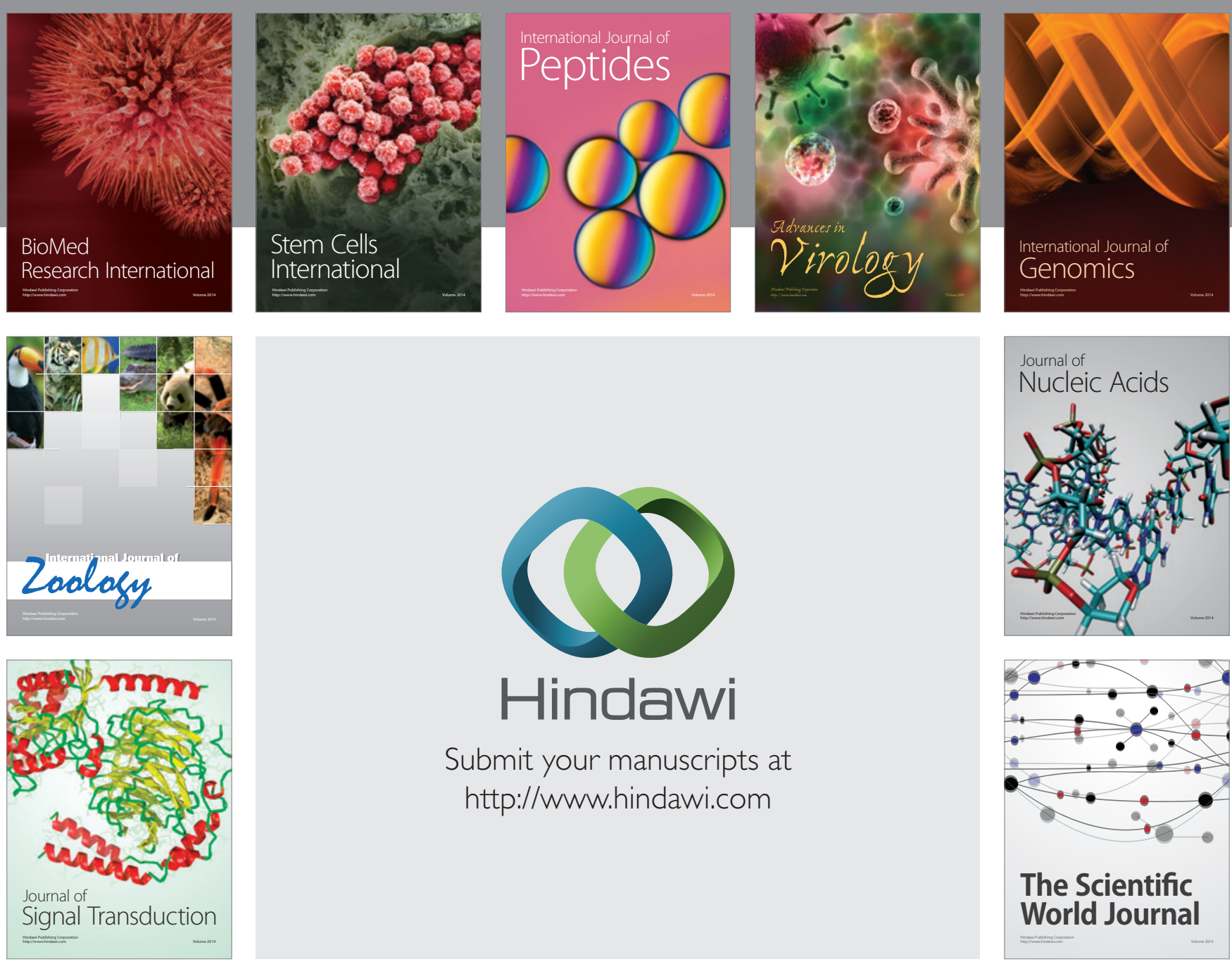

Submit your manuscripts at

http://www.hindawi.com
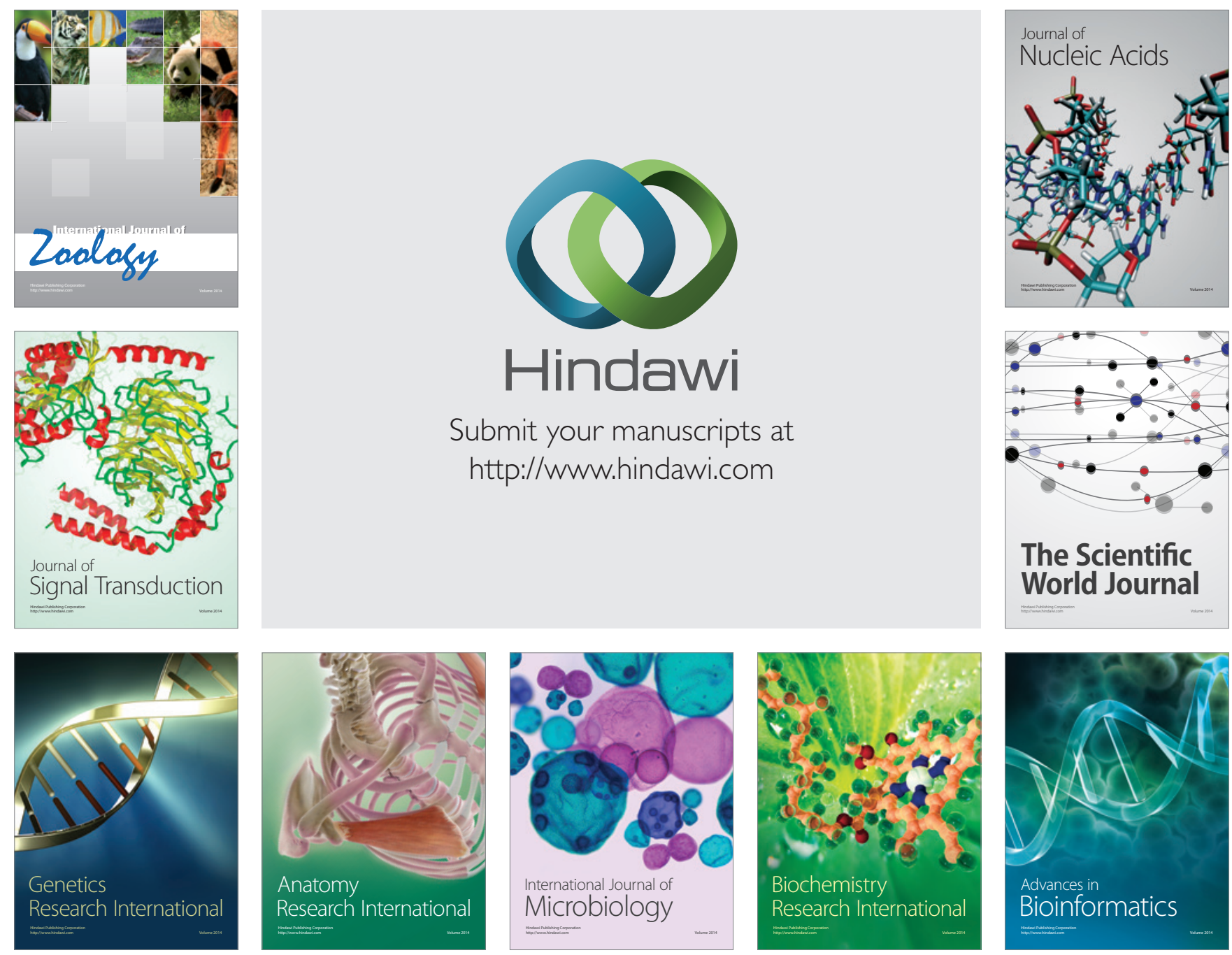

The Scientific World Journal
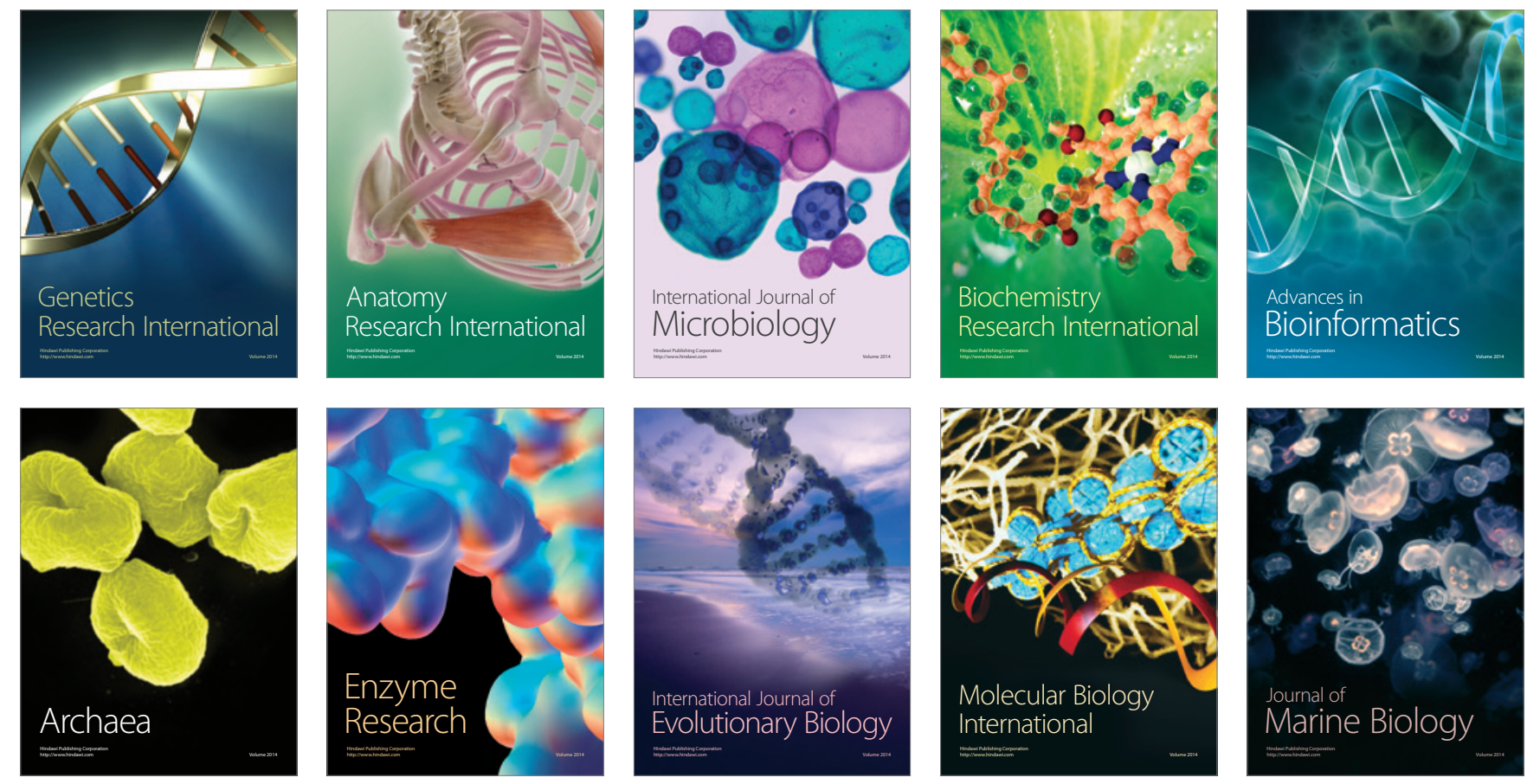